\title{
5-HYDROXYTRYPTAMINE RECEPTORS IN UTERINE SMOOTH MUSCLE
}

\author{
Fikry H. Osman and E.M. Ammar \\ Department of Pharmacology, Faculty of Medicine, \\ Assiut University, Assiut, Egypt \\ Accepted July 17, 1975
}

\begin{abstract}
When studying some of the properties of 5-hydroxytryptamine (5HT) receptors in the rat uterine muscle using phenoxybenzamine (PBZ) as an antagonist it was found that the specific receptors for $5 \mathrm{HT}$ in the smooth muscle were selectively blocked by PBZ; a period of 20-minute exposure to the antagonist was required for maximal effect. The blockade produced was of long duration and the recovery of response was relatively slow; it was incompletc throughout the 4-hour obscrvation period. A concentration of $1 \times 10^{-3} \mathrm{~g} / \mathrm{ml}$ PBZ produced a parallel shift of the doseresponse effects while higher concentrations reduced both the slope and maximal response. The reasons for such a shift were discussed. $5 \mathrm{HT}$ produced a rapid onset and offset of effect suggesting that the site of 5HT receptor is on the surface of the cell membrane. Moreover, 5HT could protect its own receptor against PBZ blockade.
\end{abstract}

5-Hydroxytryptamine (5HT) has been shown to produce its responses by activating two types of specific receptors. Depending on the selectivity of a variety of antagonists they are classified into $\mathrm{M}$ - and D-receptors. The first is present in nervous tissues and is blocked by morphine while the latter is present in smooth muscles and is blocked by dibenzyline (phenoxybenzamine) (1). Their distribution is, however, disputed and Innes \& Kohli (2) have shown that smooth muscles may contain both types of receptors. A variety of smooth muscle preparations on which $5 \mathrm{HT}$ elicits a measurable response have been subjected to investigations and variation in the sensitivity of different smooth muscles to 5HT has been reported (3). The rat uterus is very sensitive and contracts in response to 5HT; the effect can be antagonized specifically by LSD and related compounds ( 3 ). The use of phenoxybenzamine (PBZ) as a 5HT receptor antagonist has been studied in some smooth muscle preparations (4) but not in the rat uterine muscle. The object of the present study was to explore some of the characters of $5 \mathrm{HT}$ receptors in the rat uterine muscle by using PBZ as an antagonist and in doing so the following points have been posed for investigation: (1) dose response of $5 \mathrm{HT}$ using different concentrations of $\mathrm{PBZ}$, (2) duration of blockade produced by $\mathrm{PBZ}$ on $5 \mathrm{HT}$ receptors, (3) influence of $5 \mathrm{HT}$ receptor blocking dose of PBZ on other receptors as well namely, acetylcholine and oxytocin, (4) self-protection of $5 \mathrm{HT}$ receptors against $\mathrm{PBZ}$ blockade and (5) cross-protection to other receptors if they are to be affected by $P B Z$ using different concentrations of agonists.

\section{MATERIALS AND METHODS}

\section{Tisstie preparation}

Adult female rats weighing between $150-200 \mathrm{~g}$ were injected with diethylstilbestrol in 
a daily dose of $0.1 \mathrm{mg} / \mathrm{kg}$ s.c. at least 48 hours before sacrifice. The rats were sacrificed by a sharp blow on the head and the abdomen opened. The two horns of the uterus were excised and placed in a beaker containing oxygenated Krebs medium of the following composition (mM); $\mathrm{NaCl} 116 ; \mathrm{KCl} 4.6 ; \mathrm{CaCl}_{2} 1.5 ; \mathrm{MgSO}_{4} 1.2 ; \mathrm{NaHCO}_{3} 22 ; \mathrm{NaH}_{2} \mathrm{PO}_{4}$ 1.2; D-glucose 5.0. The uterine horns were cleaned of fat and connective tissue and each horn was opened lengthwise so that the preparation was a thin sheet of muscle instead of a narrow tube. Each uterine horn was divided longitudinally so that a total four picees were obtained from each animal. The preparations were suspended in organ baths of $30 \mathrm{ml}$ working volume containing oxygenated Krebs solution at room temperature $\left(22^{\circ} \mathrm{C}\right)$; at this temperature the spontaneous rhythmic contractions were practically abolished. Contractions were recorded isometrically by means of force displacement transducers connected to a physiograph.

Drugs used

The drugs used are 5-hydroxytryptamine creatine phosphate (5HT), acetylcholine chloride (ACh), phenoxybenzamine hydrochloride (PBZ) and oxytocin and they were expressed as $\mathrm{g}$ per $\mathrm{ml}$ of bathing medium. They were dissolved in distilled water excepl for PBZ which was dissolved in distilled water containing $0.01 \mathrm{M} \mathrm{HCl}$. One tenth $\mathrm{ml}$ of an appropriate dilution was added to the organ baths to give the required concentrations. The concentrations of the first three drugs were expressed in terms of their salts.

\section{Dose-response experiments}

After the tissucs had been suspended in the organ baths they were allowed to equilibrate for one hour and the increase in tension produced by different concentrations of the agonists was recorded. In all cases the agonist was left in contact with the tissues for 2 min and was washed out after each dose. After the tissue had returned to the resting tension, an interval of 3 min was allowed before the administration of the next dose.

In order to determine the exposure time required to cause complete blockade of the tissues to the antagonist, PBZ was added to the uterine preparations and left in contact with the tissues for varying time periods. After each time period PBZ was washed with Krebs solution; a test dose of $5 \mathrm{HT}$ was added and the response observed. In determining the dose-response relationship when different concentrations of PBZ were used, the antagonist was left in contact with the tissues for $20 \mathrm{~min}$ (Figure 2) and the dose-response effects were determined immediately, $1.5 \mathrm{hr}$ and $4 \mathrm{hr}$ after the end of exposure to PBZ.

\section{Self-protection experinents}

In this study the procedure devised by Furchgott (5) was used. In these experiments $5 \mathrm{HT}$ was added to the experimental preparation first, and 5 min later PBZ was added. After 20 min exposure to PBZ both drugs were washed out and two to three additional washes were generally made at intervals of 5 min. The response to 5HT was determined after the experimental strips had relaxed fully from the contraction produced by $5 \mathrm{HT}$. The control preparations in these experiments were treated in a manner similar to the experimental strips except that no $5 \mathrm{HT}$ was added along with PBZ. 


\section{Expression of results}

The results are expressed in terms of the percent response of the initial control tension produced by $10^{-6} \mathrm{~g} / \mathrm{ml} 5 \mathrm{HT}$.

\section{RESULTS}

The possibility of change in the uterine muscle response to $5 \mathrm{HT}$ during the course of the experiment was studied. Dose response curves obtained from the uterine strips immediately after the equilibration period, and $1.5 \mathrm{hr}$ and $4 \mathrm{hr}$ thereafter are shown in Fig. 1. It can be seen here that the response does not change greatly throughout the period of the experiment. As already pointed out the response is expressed in terms of the percentage of the initial response obtained with 5HT concentrations of $10^{-6} \mathrm{~g} / \mathrm{ml}$. Higher concen-

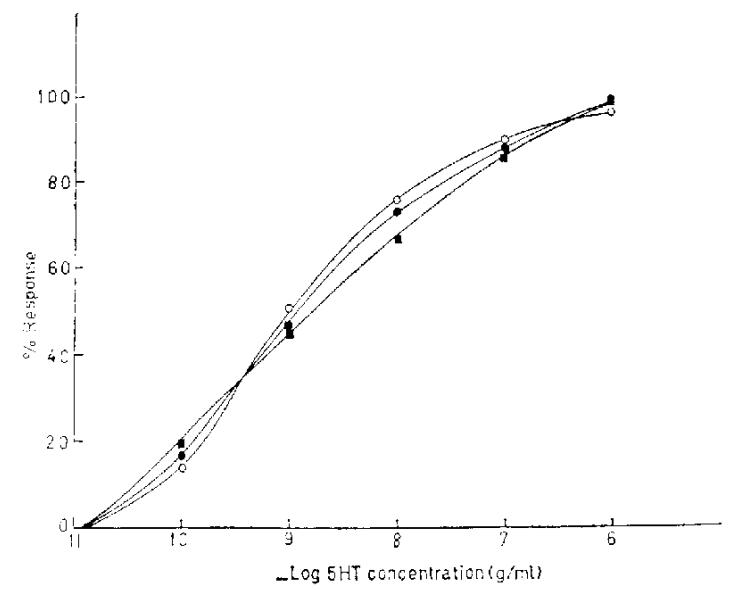

FIG, 1. Dose-response curves for $5 \mathrm{HT}$.

response after $1.5 \mathrm{hr}$; least 6 observations.

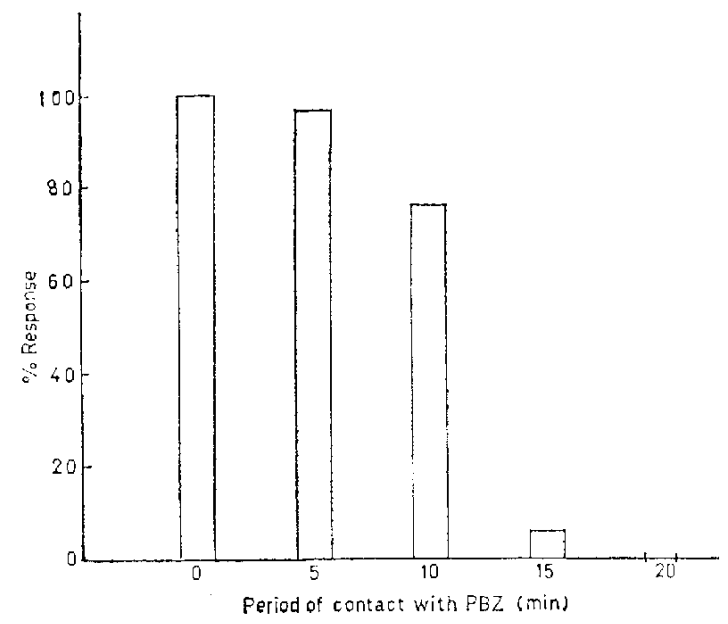

FIG. 2. Relationship between duration of tissue exposure to PBZ $10^{-6} \mathrm{~g} / \mathrm{ml}$ and response to $5 \mathrm{HT} 10^{-6} \mathrm{~g} / \mathrm{ml}$. Each bar represents the mean of at least 6 observations. 


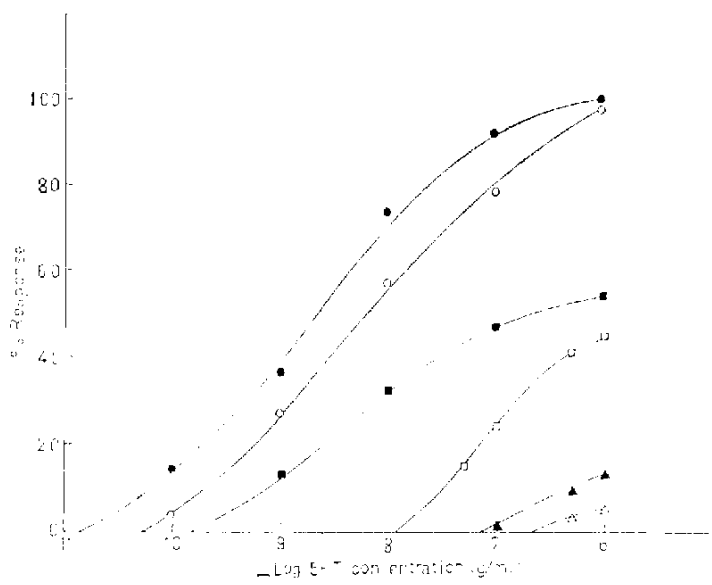

Fig. 3. Effoct of various concentrations of PBZ on the dose-response curves for

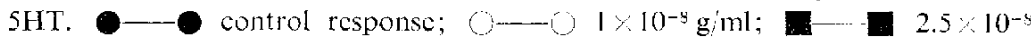

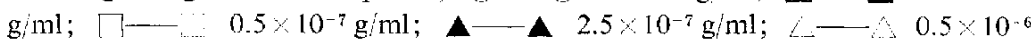
giml. PBZ was left in contact with the tissues for $20 \mathrm{~min}$. Each point represents the mean of at least 6 observations.

trations were, however, avoided. The likelihood of auloinhibition obtained with higher concentrations was a major determinant in setting up our highest level to $10^{-6} \mathrm{~g} / \mathrm{ml}$. A point worth-mentioning is the rapidity with which the uterine muscle contracts in response to $5 \mathrm{HT}$ and relaxes when it is washed out.

In determining the time required for PBZ to exert its maximal effect, a high concentration of PBZ was used in order to saturate all 5HT receptor sites. The results presented in Fig. 2 show the uterine response to $10^{-6} \mathrm{~g} / \mathrm{ml} 5 \mathrm{HT}$ after the tissues have been exposed to $10^{-6} \mathrm{~g} / \mathrm{ml} \mathrm{PBZ}$ for different time periods. The response was markedly reduced after PBZ has been left in contact with the tissues for $15 \mathrm{~min}$ and after $20 \mathrm{~min}$ the response was practically abolished. This relatively long period required for PBZ to produce its complete effect is probably the result of the formation of a reactive quaternary cthyleniminium derivative that reacts strongly with the receptor via a covalent bond (6).

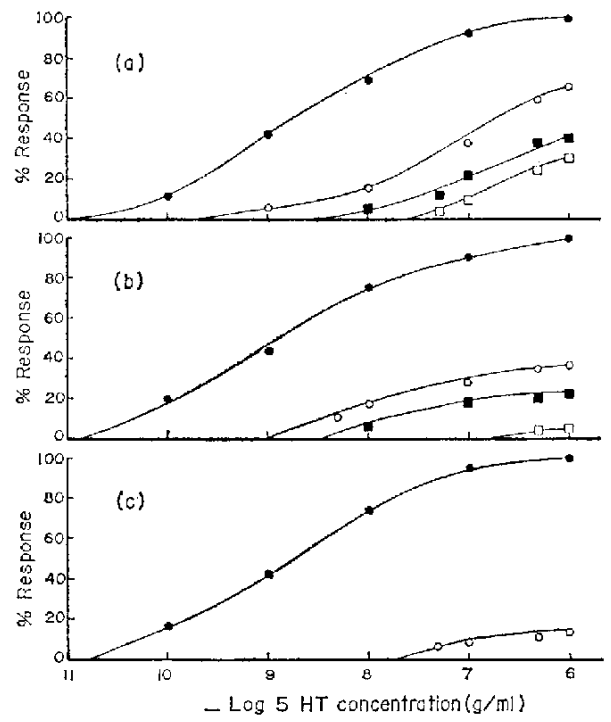

FIG. 4. Dose-response curves for 5HT following the administration of: (a) $1 \times 10^{-7} \mathrm{~g} / \mathrm{ml}$ PBZ for $20 \mathrm{~min}$. (b) $5 \times 10^{-7} \mathrm{~g} / \mathrm{ml} \mathrm{PBZ}$ for $20 \mathrm{~min}$. (c) $0.75 \times 10^{-6} \mathrm{~g} / \mathrm{ml} \mathrm{PBZ}$ for $20 \mathrm{~min}$. - - control response; $O-O$ response after $4 \mathrm{hr}$; $-\mathrm{m}$ response after $1.5 \mathrm{hr}$; [1.-- inmediate response. Each point represents the mean of at least 6 observations. 
The dose-response curves following the exposure of the tissues to various concentrations of PBZ for 20 min are depicted in Fig. 3. It is evident that the smallest concentration of $\mathrm{PBZ}, 1 \times 10^{-8} \mathrm{~g} / \mathrm{ml}$, produced a more or less parallel shift of the dose response curve and a near maximal response was attained. Blockade with higher concentrations, however, produced non-parallel shifts to the right as well as a progressive decline in the maxima. When the concentration of $0.75 \times 10^{-5} \mathrm{~g} / \mathrm{ml}$ was reached, complete blockade was achieved and the uterine preparation was no longer responsive to the test doses of 5HT.

Uterine tissues incubated with different concentrations of PBZ for 20 min showed right and downward shifts in the dose response curves immediately after incubation and at $1.5 \mathrm{hr}$ and $4 \mathrm{hr}$ (Fig. 4). With PBZ concentrations of $1 \times 10^{-7} \mathrm{~g} / \mathrm{ml}$ and $5 \times 10^{-7} \mathrm{~g} / \mathrm{ml}$ there was still a measurable response to $5 \mathrm{HT}$ immediately after the incubation. Gradual recovery of response, although incomplete, took place after 1.5 and $4 \mathrm{hr}$. With the highest concentration $\left(0.75 \times 10^{-6} \mathrm{~g} / \mathrm{ml}\right)$ there was no detectable response to $5 \mathrm{HT}$ for up to 4 hr where

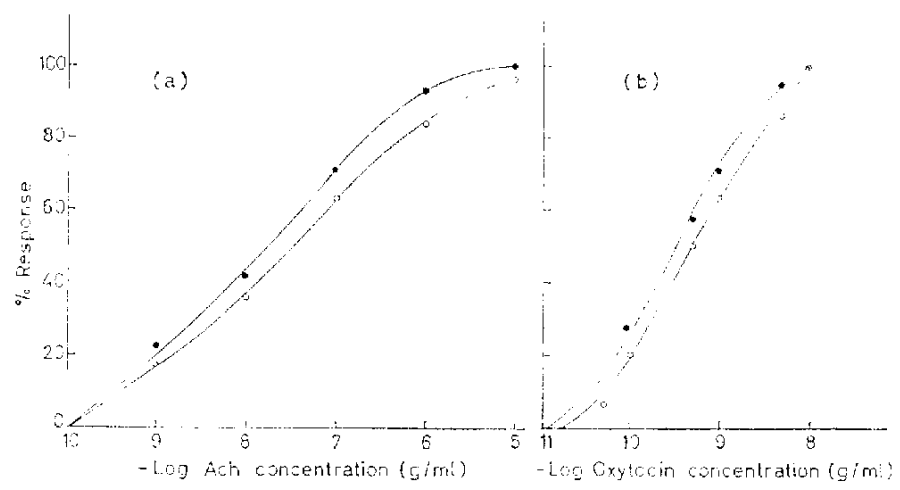

FiG. 5. Dose-response curves for: (a) ACh and (b) oxytocin following the administration of $0.75 \times 10^{-8} \mathrm{~g} / \mathrm{ml} \mathrm{PBZ}$ for $20 \mathrm{~min}$.<smiles>[Os]</smiles>
control response; immediate response after PBZ. Each point represents the mean of at least 6 observations.
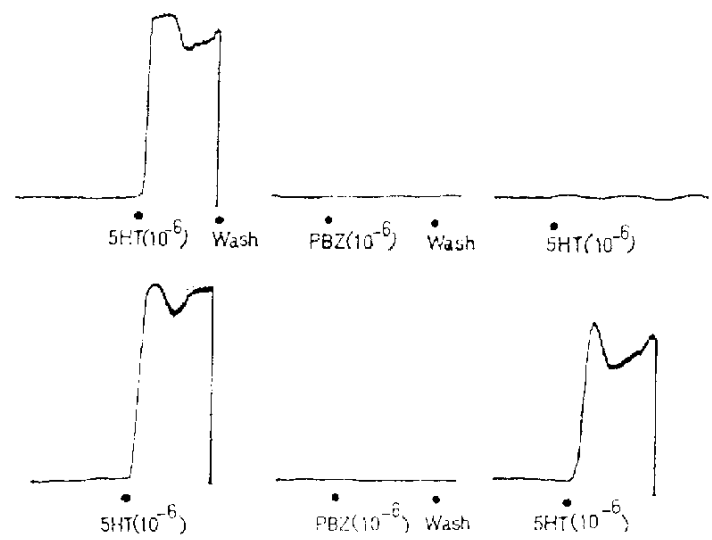

Fic. 6. Self-protection of 5 HT receptors against PBZ blockade. The upper tracing represents the control unprotected situation while the lower tracing represents the test-protected situation. 
some recovery was observed. When this blocking dose of $\mathrm{PBZ}\left(0.75 \times 10^{-6} \mathrm{~g} / \mathrm{ml}\right)$ was tested against $\mathrm{ACh}$ and oxytocin receptors (Fig. 5) no marked change was observed denoting the specificity of PBZ for $5 \mathrm{HT}$ receptors.

In studying the receptor protection against blockade by $\mathrm{PBZ}$, the response of the rat uterus to 5HT was measured before and after exposure to PBZ. A representative form of this study is illustrated in Fig. 6. It can be seen that PBZ abolished the response to 5HT in all unprotected preparations. In protected strips the effect of $\mathrm{PBZ}$ on the response to subsequent addition of $5 \mathrm{HT}$ was much less. In some cases, however, self-protection with 5HT was not observed.

\section{DISCUSSION}

The foregoing results demonstrate that PBZ in the uterine smooth muscle blocks the response to 5HT while affecting little the response to other contractile agents. This is in contrast to its effect on the vascular and intestinal smooth muscles where it is nonspecific as it blocks, in addition to $5 \mathrm{HT}$ receptors, other contractile receptors as well $(5,7)$. Since exposure of the uterine tissue to PBZ did not eliminate the contraction produced by ACh or oxytocin, it could be concluded that the inhibition of the response to $5 \mathrm{HT}$ is actually the result of drug antagonism and not due to general depression of the contractile process or metabolism. Moreover, the self-protection experiments afford strong evidence that PBZ blocks the response to $5 \mathrm{HT}$ by inactivating the receptors with which $5 \mathrm{HT}$ itself combines and not by inactivating some other site in the pathway between the initial drug-reccptor interaction and the final contraction process.

The blockade produced by $\mathrm{PBZ}$ on 5HT receptors is of long duration and the rate of recovery is relatively slow. The very gradual recovery of the uterine response to 5HT after PBZ blockade may be due to synthesis of new receptors other than those inactivated by PBZ or recovery of the sensitivity of blocked receptors as a result of a very slow reaction setting them in free form (5). The difference in recovery rates following the use of different concentrations of PBZ favors the second possibility.

The rapidity with which the uterine muscle contracts on addition of $5 \mathrm{HT}$ and relaxes when it is washed out suggests that the primary site of the 5HT receptor is on the outside of the cell membrane. 5HT has been shown to pass through the cell membrane very slowly (8) presumably because of its low solubility in lipids. Moreover, when the efflux of 5HT was measured, it was found that most of the amine was lost rapidly at an exponential rate which was similar to that for the loss of the extracellular marker, inulin (3). Such observations lend support to the previous conclusion. A more affirmative work that can be suggested to further investigate this point is the use of tritium-labeled 5HT and its localization by appropriate autoradiographic technics.

If the response produced by $5 \mathrm{HT}$ is proportional to the concentration of the receptoragonist complex, then the addition of $\mathrm{PBZ}$ would produce a decrease in the number of active receptors and there will be a decrease in maximum and in slope of the log dose-response curves but no parallel shift of the curves along the log dose axis. Our experimental 
findings, however, have shown that progressive blockade of $5 \mathrm{HT}$ receptors by PBZ led to a shift as well as a decrease in maximum and slope and the shift was appreciable before the decrease was detectable. Such a shift can have more than one explanation. First, without discarding the assumption of proportionality between response and receptor occupancy, it might be suggested that low concentrations of PBZ interact with a special site in the neighborhood of $5 \mathrm{HT}$ receptor site, thereby inducing a conformational change at the 5HT receptor (9). The consequence would be a decreased affinity for $5 \mathrm{HT}$ and a shift of the dose-response curve but at higher concentration of PBZ the receptor itself would be inactivated leading to a decrease in the maximum response. The degree of shift will depend on the relative ease of alkylation of the two sites. Thus it can be assumed that in the rat utcrine muscle PBZ would interact with a limited number of neighboring sites before the receptor itself was inactivated, thus providing a small shift in the dose-response curve.

Secondly, this shift may provide evidence for the spare receptor concept and against the concept that the effect is proportional to the concentration of the receptor-agonist complex (10). As the degree of shift is indicative of the amount of receptor rescrve, it seems that in the rat uterine muscle there is a small receptor reserve. This spare receptor hypothesis, however, lacks any plausible molecular basis and requires a hierarchy of receptors with graded affinities for $5 \mathrm{HT}$ and PBZ.

Thirdly, the shift might be due to a prolonged competitive phase of action rather than inactivation of the receptor (11).

\section{REFERENCES}

1) Gaddum, J.H. And Pichrell, Z.P.: Brit. J. Pharmacol, 12, 323 (1957)

2) InNes, I.R. AND KoHLI, J.D.: Brit. J. Pharmacol. 35, 383 (1969)

3) Born, G.V.R.: Smooth Muscle, Edited by Bülbring, E., Brading, A.F., Jonls, A.W. and TomirA, T., Chapter 14, Edward Arnold (Publishers) Ltd., London (1970)

4) Offenmeter, J. and Ariens, E.J.: Archs int. Pharmacodyn. Ther. 164, 192 (1966)

5) Furchgott, R.F.: J. Pharmacol. exp. Ther. 111, 265 (1954)

6) Harvey, S.C. and Nickerson, M.: J. Pharmacol. exp. Ther. 112, 274 (1954)

7) Cook, D.A.: Brit. J. Pharmacol. 43, 197 (1971)

8) BORN, G.V.R.: I. Physiol. 161, 160 (1962)

9) Goldstein, A., Aronow, L. And Kalman, S.M.: Principles of Drig Action. Hocber Medical Division, Harper \& Row Publishers, New York, Chapter 1 (1968)

10) Furchgott, R.F.: A. Rev. Phamacol. 4, 21 (1964)

11) Moran, J.F., Triggle, C.R. and Triggle, D.J.: J. Pham. Pharmacol. 21, 38 (1969) 